удК 343.3

DOI https://doi.org/10.32837/pyuv.v2i3(28).380

B. В. Серzійчук

аспірант кафедри крилінального права, кримінологї̈, иивільного та господарського права Національної академії управління

\title{
ДОСВІД ДЕЯКИХ ЗАРУБІЖНИХ КРАЇН ЩОДО КРИМІНАЛЬНО-ПРАВОВОЇ ОХОРОНИ ДЕРЖАВНОЇ ТАЕМНИЦІ
}

Ефективна система охорони державної таємниці є однією з гарантій збереження цілісності та недоторканості будь-якої держави, незалежно від іï місцезнаходження нагеографічній мапі світу йекономічного розвитку. В умовах збройного конфлікту на Сході України це питання набуває особливої актуальності, потребує детального дослідження на науковому рівні та належного законодавчого врегулювання. Одним із найефективніших шляхів здійснення цього є дослідження системи охорони державної таємниці закордонних країн для запозичення їхнього позитивного досвіду.

Деякі аспекти охорони державної таємниці Естонії, Франції й Узбекистану розглядалися такими науковцями, як: Д.С. Усов, С.М. Сидоренко, О.Г. Корченко, О.Є. Архипов та ін.

Мета статті - опрацювання на основі дослідження законодавчої системи охорони державної таємниці в Естонії, Франції, Узбекистані та порівняння 3 українським досвідом у цій сфері рекомендацій щодо вдосконалення законодавчого регулювання системи охорони державної таємниці України.

Під час становлення та розвитку держави виникає необхідність у захисті інформації, саме тієї інформації, від якої залежить безпека громадян і обороноздатність держави. Базові основи забезпечення охорони державної таємниці закладені в законодавстві відповідної держави, детальний аналіз якого дає змогу сформувати загальну картину й уявлення про систему заходів у цій сфері.

Так, питання здійснення охорони державної таємниці в Естонії регулюється Законом «Про державну таємницю та секретну інформаціїіноземних держав» (State Secrets and Classified Information of Foreign States Act). Відповідно до цього Закону, державна таємниця - інформація, яка вимагає охорони від розкриття в інтересах національної безпеки або міжнародних відносин Естонії, за винятком секретної інформації іноземних держав. Залежно від ступеня секретна інформація поділяється на: інформацію з обмеженим доступом, конфіденційну інформацію, секретну інформацію, інформацію із грифом «Цілком таємно» [1, с. 1].

За естонським підходом до класифікації державної таємниці та її охорони у сфері національної оборони вона поділяється на: 1) інформацію, що стосується підготовки, управління й операції національної оборони, крім інформації, розкриття якої не завдало б шкоди безпеці Естонії;2) інформацію про підготовку й операції з мобілізації, за винятком інформації, розкриття якої не завдасть шкоди безпеці Естонії; 3) інформацію про запас, необхідний для організації мобілізації, за винятком інформації, розкриття якої не завдало б шкоди безпеці Естонії, або яка підлягає розголошенню за договором; 4) відомості, що стосуються військової зброї та боєприпасів естонських військ і Ліги оборони, за винятком інформації, розкриття якої не завдало б шкоди безпеці Естонії, або яка підлягає розголошенню за міжнародним договором; 5) інформацію, зібрану з радіолокаційних інформаційно-спостережних систем військ оборони; 6) інформацію щодо винаходів і досліджень, що проводяться для цілей громадського захисту, та їх результатів, за винятком інформації, розкриття якої не завдало б шкоди безпеці Естонії; 7) відомості, зібрані структурним підрозділом сил оборони, які займаються розвідкою та контррозвідкою, за винятком інформації, розкриття якої не завдало б шкоди безпеці Естонії 8) інформацію про склад, функції та розподіл бюджету структурного підрозділу сил оборони, за винятком інформації, розкриття якої не завдало б шкоди безпеці Естонії; 9) відомості про збір таємної інформації структурним підрозділом сил оборони, включаючи інформацію про методи збору інформації та про об'єкти, за винятком інформації, розкриття якої не завдало б шкоди безпеці Естонії; 10) інформацію про міжнародне співробітництво з питань розвідки та контррозвідки, що проводяться силами оборони, за винятком інформації, розкриття якої не завдало б шкоди безпеці Естонії; 11) інформацію про військово-географічні райони сил оборони та Ліги оборони, за винятком інформації, розкриття якої не завдало б шкоди безпеці Естонії [1, с. 2].

Зазначена інформація класифікується як секретна, службова або цілком таємна протягом строку від десяти до п'ятдесяти років.

Віднесення інформації або відомостей до державної таємниці закінчується: 1) після спливу строку, протягом якого інформація вважалась державною таємницею; 2) після настання спеці- 
альної події; 3) у разі дострокового припинення віднесення інформації до державної таємниці [1, с. 5].

Серед позитивних особливостей системи охорони державної таємниці в Естонії відзначається також детальний опис процедури допуску до державної таємниці, із зазначенням форм документів для його оформлення, визначенням обов'язків суб'єктів державної таємниці, процесу зниження чи підвищення ступенів секретності й особливостей зберігання носіїв державної таємниці. На нашу думку, це пов'язано насамперед із тим, що після розпаду Радянського Союзу Естонія обрала собі за орієнтир європейські країни [2, с. 20].

Законодавство Естонії грунтується на базовому Законі «Про державну таємницю та секретну інформацію іноземних держав», де зазначається, що державною таємницею є інформація, яка належить державі, перебуває під контролем держави, створена нею або для неї [3, с. 118].

Порівнюючи законодавство України й Естонії у сфері класифікації охорони державної таємниці, можна зробити висновок, що законодавство обох держав містить чітку класифікацію інформації, що становить державну таємницю за видами, підвидами та строком охорони таких відомостей. Проте, якщо в Естонії це здійснено на рівні законодавчого акта - Закону «Про державну таємницю та секретну інформацію іноземних держав», то в Україні загальний перелік інформації, що становить державну таємницю, міститься в Законі «Про державну таємницю», а більш детальна класифікація такої інформації у сфері безпеки й оборони та строк іï охорони врегульовано на підзаконному рівні - Зводом відомостей, що становлять державну таємницю, затвердженим наказом Служби безпеки України від 12 серпня 2005 р. № 440.

Крім цього, якщо у відповідному естонському Законі чітко визначено можливі ступені секретності тієї чи іншої інформації у сфері охорони державної таємниці, часові межі її охорони, то в Україні існує певна диспозитивність у цьому питанні, вирішення якого віднесено на розсуд державного експерта з питань таємниць або колегії державних експертів із питань таємниць.

Ще однією відмінністю законодавства Естонії у сфері охорони державної таємниці від аналогічного українського є те, що в Естонії існує більш широкий поділ інформації залежно від ступеня секретності та більш тривалий строк дії рішення про віднесення тієї чи іншої інформації до держаної таємниці.

Ефективна організація захисту державних таємниць в Естонії забезпечується: встановленням кримінальної (дисциплінарної) відповідальності за порушення процедури доступу до державних таємниць, порушення вимог обробки державних таємниць і носіїв секретних відомостей, а також за незаконне розсекречення державних таємниць; захистом державних таємниць від незаконного розсекречення; згодою на дотримання вимог, установлених для обробки державних таємниць і секретних носіїв [4, с. 327].

За розголошення державної таємниці чи секретної інформації іноземних держав Кримінальним кодексом Естонії встановлена відповідальність у виді ув'язнення до п'яти років, а якщо злочин учинено юридичною особою - накладенням штрафу [5, с. 55]. Також в Естонії передбачена кримінальна відповідальність за публікацію державної таємниці або секретної інформації іноземних держав через необережність у виді ув'язнення до одного року, злочин, учинений юридичною особою, карається накладенням штрафу [5, с. 55].

Варто зауважити, що в Особливій частині Кримінального кодексу Республіки Естонія не зазначено розмір штрафу, який застосовується до юридичної особи в разі вчинення того чи іншого злочину.

Мінімальні та максимальні розміри штрафу, які можуть застосовуватися до юридичної особи, встановлюються Загальною частиною Кримінального кодексу Естонії і становлять від чотирьох до шістнадцяти мільйонів євро [5, с. 7].

Серед позитивних особливостей охорони державної таємниці в Естонії через інститут кримінальної відповідальності, які відрізняють їі від інших Балтійських пострадянських країн, Д.С. Усов зазначає такі: визначення як ознак складу злочину відомостей різних ступенів секретності, відсутність спеціальних ознак суб'єкта злочину, передбачення як об'єктивну сторону складу злочину не тільки розголошення певних відомостей, а й видачу незаконного дозволу на доступ до відомостей, що становлять державну таємницю [6, с. 106].

Загалом, якщо порівнювати санкції статей Кримінального кодексу України та Кримінального кодексу Естонії, передусім за порушення у сфері охорони державної таємниці, то можна зробити висновок, що відповідальність в Україні й Естонії за такі порушення практично ідентична.

Переходячи до характеристики французького законодавства в досліджуваній сфері, зазначимо, що правові основи діяльності щодо охорони державних таємниць у Франції були закладені в 1960 р., коли держава увійшла до «ядерного клубу» - групи ядерних держав. 4 липня 1960 р. ухвалений указ про таємниці, в якому давалося досить широке трактування поняття, що визначає секретність відомостей [7, с. 125].

Сьогодні у Франції секретною є інформація оборонного значення, яка за ступенем секретності поділяється на три рівні:

- конфіденційна оборонна - інформація, розголошення якої вважається потенційно небезпеч- 
ним для національної оборони або може призвести до розкриття інформації, віднесеної до більш високого рівня безпеки;

- секретна оборонна - інформація, розголошення якої може завдати істотної шкоди національній обороні, що не може поширюватися без дозволу відповідних органів влади, крім виняткових ситуацій;

- надзвичайно секретна оборонна - інформація, розголошення якої вважається вкрай небезпечним для національної оборони, жодна організація не має права здійснювати зберігання, передачу, відображення або знищення інформації цього рівня секретності без дозволу прем'єр-міністра Франції або секретаря національної оборони; часткове або вибіркове відтворення цієї інформації також суворо заборонено [8, с. 39].

Менш чутлива 3 погляду оборони інформація у Франції визначається як «захищена» і підрозділяється на такі рівні (за зростанням): незахищена (Non Protégé); поширення обмежене адміністрацією (Diffusion restreinte administrateur); поширення обмежене (Diffusion restreinte); конфіденційно, для молодших службовців (Confidentiel personnels Sous-Officiers); конфіденційно, для службовців (Confidentiel personnels Officiers) [8, с. 38].

Кримінальний кодекс Франції [9] передбачає відповідальність за такі злочини у сфері охорони державної таємниці:

- ведення розвідки 3 іноземною владою, 3 іноземним або іноземним контрольованим підприємством чи організацією або з їхніми агентами 3 метою спровокувати військові дії або акти агресії проти Франції, що карається тридцятьма роками позбавлення волі і штрафом у розмірі 450000 євро;

- збирання 3 метою доставки іноземній державі, іноземному чи підконтрольному іноземному підприємству або організації або їнім агентам інформації, процесів, об'єктів, документів, комп'ютерних даних або файлів, використання, розголошення чи розкриття яких, імовірно, може підірвати основні інтереси нації, що карається десятьма роками позбавлення волі та штрафом у розмірі 150000 євро;

- здійснення на користь іноземної влади іноземним або підконтрольним іноземним підприємством чи організацією або їхніми агентами діяльності з метою придбання або доставки пристроїв, інформації, процесів, предметів, документів, комп'ютеризованих даних чи файлів, використання, розголошення чи розкриття яких може зачіпати основні інтереси нації, що карається десятьма роками позбавлення волі та штрафом у розмірі 150000 євро.

Цікавим є те, що у Франції рівні класифікації відомостей, технологій, предметів, документів, інформаційних даних або даних картотек, що мають характер таємниці національної оборони, згідно з якими організована їх охорона, визначаються декретом Державної ради [10, с. 352].

Проаналізувавши відповідальність за порушення охорони державної таємниці, передбачену законами про кримінальну відповідальність Франції та України, можна зробити висновок, що французьке законодавство більш суворе, ніж українське. Відповідно до Кримінального кодексу України, за злочини у сфері охорони державної таємниці передбачена кримінальна відповідальність у виді обмеження волі або позбавлення волі, лише в деяких випадках - позбавлення права займатись певною діяльністю, не передбачає фінансових санкцій, як це передбачено у Франції. Законодавство Франції порівняно з українським має ширший перелік секретної інформації у сфері оборони, у Франції секретна інформація оборонного значення додатково за ступенем секретності поділяється на три рівні (конфіденційна оборонна, секретна оборонна та надзвичайно секретна оборонна), чого немає в українському законодавстві.

В Узбекистані досліджуване нами питання врегульоване Законом «Про охорону державних таємниць». Відповідно до цього Закону, державними секретами Узбекистану є особливої важливості, цілком таємні і секретні військові, політичні, економічні, науково-технічні й інші відомості, що охороняються державою й обмежуються спеціальними переліками [11].

Державні таємниці Узбекистану поділяються на державну, військову і службову. Державну таємницю становлять відомості, розголошення яких може негативно вплинути на якісний стан військово-економічного потенціалу Республіки або спричинити інші тяжкі наслідки для обороноздатності, державної безпеки, економічних i політичних інтересів Узбекистану. Військову таємницю становлять відомості військового характеру, розголошення яких може спричинити тяжкі наслідки для обороноздатності, державної безпеки і Збройних сил Узбекистану. Службову таємницю становлять відомості в області науки, техніки, виробництва й управління, розголошення яких може завдати шкоди інтересам Узбекистану [11].

Отже, якщо порівнювати розподіл державних таємниць на види в Україні й Узбекистані, можна зробити висновок, що в Україні існує більш детальна класифікація залежно від виду відносин: у сфері оборони, у сфері економіки, науки і техніки, у сфері зовнішніх відносин, у сфері державної безпеки й охорони правопорядку, а в Узбекистані поділ здійснюється залежно від сфери, у якій така таємниця охороняється.

За розголошення державної таємниці в Узбекистані передбачена кримінальна відповідальність, зокрема розголошення або передача державних секретів, тобто відомостей, що становлять 
державну, військову або службову таємницю, особою, якій ці відомості були довірені або стали відомі у зв'язку зі службовою чи професійною діяльністю, за відсутності ознак зради державі карається обмеженням волі від трьох до п'яти років або позбавленням волі від трьох до п'яти років, а якщо це спричинило тяжкі наслідки, санкція збільшується до позбавлення волі від п'яти до восьми років [12, с. 92$]$.

Варто зазначити, що диспозиція статті - розголошення державної таємниці - у Кримінальному кодексі Узбекистану дуже схожа з відповідною диспозицією статті Кримінального кодексу України. Проте, якщо в Узбекистані об'єктивна сторона цього злочину полягає і в розголошенні, і в передачі державної таємниці, то в Україні - лише в розголошенні. За суб'єктним складом злочини майже ідентичні - особа, якій такі відомості довірені або відомі у зв' язку з її службовою діяльністю.

Крім розголошення державної таємниці, кримінально караним діянням в Узбекистані у сфері охорони державної таємниці також є втрата документів, що становлять державну таємницю, зокрема втрата документів, а також предметів або речовин, відомості про які становлять державну або військову таємницю, особою, якій вони були довірені у зв'язку зі службовою чи професійною діяльністю, якщо втрата стала наслідком порушення правил поводження із зазначеними документами, предметами або речовинами [12, с. 92].

Проведене порівняльно-правове дослідження продемонструвало деякі позитивні моменти закордонного досвіду щодо правового регулювання питань охорони державної таємниці. На нашу думку, найбільш позитивними є деякі підходи естонського та французького досвіду в зазначеній сфері, що може бути імплементований в українське законодавство.

Так, варто розглянути питання щодо внесення зміни до Закону України «Про державну таємницю» та закріпити перелік таємної інформації на рівні Закону, зокрема включити до нього строки охорони та класифікацію за ступенем секретності кожного з видів інформації, що становить державну таємницю.

Також доцільно внести зміни до Кримінального кодексу України, зокрема:

- визначити (за естонським досвідом) суб'єктом злочинів у сфері охорони державної таємниці також юридичну особу з відповідальністю у виді штрафу;

- посилити (за французьким досвідом) покарання за злочини у сфері охорони державної таємниці, за які може застосовуватися покарання у виді позбавлення волі на строк до тридцяти років, узгодити загальну частину Кримінального кодексу України.
Крім того, ураховуючи необхідність розвитку України у сфері оборони, уважаємо за необхідне систематизувати, за прикладом Франції, перелік секретної інформації у сфері оборони, поділивши iї на три рівні: конфіденційна оборонна, секретна оборонна, надзвичайно секретна оборонна.

\section{Jimepamypa}

1. Про державну таємницю та секретну інформацію іноземних держав : Закон Естонської Республіки (State Secrets and Classified Information of Foreign States Act). URL: https://www.riigiteataja.ee/en/eli/ ee/501042019009/consolide.

2. Грищенко I.В. Досвід країн Східної Європи у сфеpi охорони державної таємниці. Порівняльно-аналітичне право. 2015. С. 19-22.

3. Корченко О.Г., Архипов О.Є., Дрейс Ю.О. Оцінювання шкоди національній безпеці України в разі витоку державної таємниці : монографія. Київ : Наук.-вид. центр НА СБ України, 2014. 332 с.

4. Сидоренко С.M. Організаційно-правові засади охорони державної таємниці Естонської Республіки. Національна академія Служби безпеки України. 2018. C. 327-329.

5. Кримінальний кодекс Республіки Естонія. 2001. URL: https://www.riigiteataja.ee/en/eli/ee/Riigikogu/ act $/ 516052019002 /$ consolide.

6. Усов Д.С. Захист державної таємниці за кримінальним законодавством інших країн на пострадянському просторі. Публічне право. 2013. С. 103-109.

7. Зайцева-Калаур I.В. Опорний конспект лекцій 3 дисципліни «Охорона державної та комерційної таємниці». ТНЕУ. 2018. $147 \mathrm{c.}$

8. Косминя А.П. Аналіз системи охорони державної таємниці у Франції. Інтернаука : міжнародний науковий журнал. 2017. № 1 (1). С. 38-40.

9. Кримінальний кодекс Франції. URL: https://www.legifrance.gouv.fr/affichCode.do; jsessionid=37A505566D0755937CE8328830F89F4F. tplgfr29s_1?cidTexte=LEGITEXT000006070719\&date Texte $=20 \overline{1} 90727$.

10. Уголовный кодекс Франции / научн. ред. : Н.Е. Крылова, Л.В. Головко. Санкт-Петербург, 2002. 648 c.

11. Про охорону державних таємниць : Закон Республіки Узбекистан від 7 травня 1993 р. № 848-XII. URL: http://www.lex.uz/acts/98845.

12. Кримінальний кодекс Республіки Узбекистан. URL: http://www.lex.uz/acts/111457\#163893.

\section{Анотація}

Сергійчук В. В. Досвід деяких зарубіжних країн щодо кримінально-правової охорони державної таємниці. - Стаття.

У статті наведено детальний аналіз систем охорони державної таємниці у Франції, Естонії й Узбекистані, які були порівняні із системою охорони державної таємниці України. У процесі вищезазначеного аналізу було досліджено закордонне законодавство щодо систем захисту державної таємниці та положення місцевих кримінальних кодексів щодо охорони державної таємниці як механізм захисту державної таємниці. Порівнювались вид і розмір покарання за вчинення злочинів, пов'язаних із розголошенням інформації, що становить державну таємницю, у Франції, Естонії, Узбекистані й Україні. У результаті було з'ясовано, що найсуворіше покарання за розголошення державної 
таємниці передбачене Кримінальним кодексом Франції та становить до тридцяти років позбавлення волі, тоді як Кримінальний кодекс Узбекистану передбачає позбавлення волі до п'яти років. Найбільш детальна класифікація інформації, що становить державну таємницю, існує в Естонії, де вся інформація розподілена на класи та підкласи, для кожного такого класу і підкласу визначаються тип секретності та термін охорони її державою. На основі всієї дослідженої інформації та документів ми пропонуємо внести зміни до відповідних положень Кримінального кодексу України та Закону України «Про державну таємницю», щоб запозичити найкращий європейський досвід, зокрема ми пропонуємо встановити кримінальну відповідальність для юридичних осіб за розголошення державної таємниці та посилити покарання за злочини у сфері охорони державної таємниці. Більше інформації та цікавих фактів ви можете знайти, прочитавши повну версію статті.

У зв'язку з необхідністю розвитку України в галузі оборони ми запропонували систематизувати перелік секретної інформації в галузі оборони, розділивши іiі на три рівні: конфіденційна оборонна, секретна оборонна, надзвичайно секретна оборонна.

На основі закордонного досвіду кримінально-правової охорони державної таємниці зроблено висновки щодо необхідності вдосконалення українського законодавства у сфері охорони відомостей, що становлять державну таємницю.

Ключові слова: охорона, державна таємниця, система охорони державної таємниці, національна безпека, секретна інформація.

\section{Summary}

Serhiichyk $V . V$. The experience of some foreign countries on criminal-legal protection of state secrets. Article.

The article contains the detailed analysis of the state secret protection systems in France, Estonia and Uz- bekystan which were compared to the state secret protection system of Ukraine. In process of the abovementioned analysis the local laws on systems of the state secret protection and provisions of local criminal codes regarding protection of the state secrets were investigated as a mechanism of the state secrets protection. The type and amount of a punishment for commitment of the crimes related to the disclosure of state secret information in France, Estonia, Uzbekistan and Ukraine were compared. As a result it was found out that the toughest punishment for disclosure of state secrets stipulated by the Penal Code of France is up to thirty years of the imprisonment while the Criminal Code of Uzbekystan is up to five years. The most detailed classification of an information as constituting the state secrets is in Estonia, namely all information divided into the classes and subclasses and for each such class and subclass the type of the secrecy and term of the state protection are stipulated. Based on all investigated information and documents we propose to amend the respective provisions of the Criminal Code of Ukraine and Law of Ukraine On state protection secrets to bring it into line with the best European experience, namely we propose to establish criminal liability for legal entities for disclosure of state secrets and aggravate the punishment for the respective crimes. More information and interesting facts you may find by reading the full version of the article.

Due to the necessity of development of Ukraine in the sphere of defense we proposed to systematize the list of classified information in the field of defense, dividing it into three levels: confidential defense, secret defense, extremely secret defense.

Based on foreign experience of the criminal protection of the state secrets, it was resolved what there is a need to improve Ukrainian legislation in the sphere of protection of information being the state secrets.

Key words: protection, state secret, system of protection of state secret, national security, secret information. 